\title{
On the Relationship between Heat Waves over the Western and Central Europe and NAO, SOI, El-Nino 3.4 in Summer 2015
}

\author{
Yehia Hafez \\ Department of Meteorology, King Abdulaziz University, Jeddah, Saudi Arabia \\ Email: ysalam@kau.edu.sa
}

How to cite this paper: Hafez, Y. (2017) On the Relationship between Heat Waves over the Western and Central Europe and NAO, SOI, El-Nino 3.4 in Summer 2015. Journal of Geoscience and Environment Protection, 5, 31-45.

https://doi.org/10.4236/gep.2017.54004

Received: February 24, 2017

Accepted: April 16, 2017

Published: April 19, 2017

Copyright $\odot 2017$ by author and Scientific Research Publishing Inc. This work is licensed under the Creative Commons Attribution International License (CC BY 4.0).

http://creativecommons.org/licenses/by/4.0/

\begin{abstract}
An extreme warming hit Europe in summer of the year 2015. The present paper investigates the relationship between the North Atlantic Oscillation Index (NAO), Southern Oscillation Index (SOI) and El-Nino 3.4 and heat waves that persist over the western and central Europe in the summer of 2015. The NCEP/NCAR Reanalysis daily dataset of the mean surface air temperature for the domains of the western and central Europe for summer months (June, July and August) of the year, 2015 has used. In addition, the time cross-section analysis of the daily gridded operational data for the mean surface air temperature over the western and central Europe from 1 June to 31 August 2015 has done. Moreover, daily datasets of the NAO, SOI, and El-Nino 3.4 for that period have used. The time series, time cross section, anomaly and correlation coefficient techniques are used to analyze the data sets. The results revealed that the cases of heat waves that existed over the western and central Europe through the summer season of the year 2015 were controlled distinctly by the negative phase of the NAO and positive phase of ENSO.
\end{abstract}

\section{Keywords}

Heat wave, Surface air Temperature, The Western and Central Europe, NAO, SOI, El-Nino 3.4

\section{Introduction}

Heat waves have been the most prominent hazard over Europe. Europe has deadly heat events. Tragic 2003 heat wave has 70,000 fatalities. Recently, the western and central Europe are hit by successive heat waves during the summer of 2015. Almost all of European countries are affected by heat waves. However, the western and central Europe are in the control of a record-breaking heat 
wave. In Spain, Madrid set a new record of temperature $39.9^{\circ} \mathrm{C}$ on 6 July. It also has recorded high temperature $39.7^{\circ} \mathrm{C}$ on 29 June. German heat records were on 4-5 July 2015. Berlin has a temperature of $37.9^{\circ} \mathrm{C}$ and Frankfurt soars to $39^{\circ} \mathrm{C}$ [1]. In France, several monthly temperature records have broken during the July of summer 2015 [2]. However, the European heat wave has spread to Belgium and the Netherlands, as well as Germany. As unusual, Dusseldorf's temperature was of $36.1^{\circ} \mathrm{C}$ and it was almost $22^{\circ} \mathrm{C}$ above its normal value. Recently there are several studies in the scientific literature of heat waves and its impacts on several sectors and fields in distinct regions over the globe. [3] (2010) reviewed the European summer heat wave of 2003; they found that anomalous Mediterranean Sea surface temperature (SSTs) had contributed to the heat wave of 2003. For heat wave over Russia in 2010, [4] studied the seasonal predictability of a heat wave. They found that the atmospheric blocking over Europe led to the development of a Russian heat wave. [5] found that the Euro-Mediterranean region had an increase in extreme temperature events. Moreover, "Mega-heatwaves" such as the 2003 and 2010 events broke the 500-year temperature records over $50 \%$ in Europe [6]. However, there are several scientific kinds of literature challenge of the abnormal extreme weather conditions, e.g. [7] [8]. The North Atlantic Oscillation (NAO) is one of the most prominent teleconnection patterns [9]. NAO uses differences in sea level pressure (SLP) at two stations Gibraltar and Iceland [10]. Both positive and negative phases of the NAO are associated with basin-wide changes in the synoptic weather conditions over the North Atlantic [11]. [11] [12] found that the NAO was accompanied by changes in the system of wester winds across the North Atlantic onto Europe. In addition to that, land surface anomalies preceding the 2010 Russian heat wave were a link to the variation of the NAO [13]. [14] found that summer heat waves over the western Europe 1880-2003, had related to large-scale forcing. The Southern Oscillation Index (SOI) is coupled with El-Nino, which is called ENSO phenomena. ENSO occurrences global climate changes that linked to various climatic anomalies. However, El-Nino can have severe consequences for the weather and living conditions on earth, [15] and more recently [16]. There is a several study illustrate that ENSO has a significant influence on the heat waves and climate variability in many parts of the globe, (e.g., [7] [17] and [18] [19] [20]). A heat wave is a prolonged period of excessively hot weather. There is no universal exact definition of a heat wave. The term, heat wave, is relative to the usual weather in the area. This term applied in the both of routine weather variations and in extraordinary spells of heat, which may occur only once a century. In fact, the frequency and disasters of the heat waves become significant issue through the last decades. Therefore, the teleconnection between the climatic indices, NAO, SOI and ElNino, and the existence of heat waves over Europe is very important to discuss. The present work aims to study the relationship between heat waves that existed over the western and central Europe and the NAO, SOI and El-Nino 3.4 during the summer season of the year 2015. 


\section{Data and Methodology}

\subsection{Data}

The daily data set of NCEP-NCAR reanalysis of the surface air temperature over the western and central Europe of a summer season (1 June-31 August) of the year of 2015 is used. This data supported from the NOAA/OAR/ESRL PSD, Boulder, Colorado, USA and [21]. The daily data set for gridded operational surface air temperature have global grid points of $(144 \times 73)$. This data of the surface temperature have a resolution of $\left(2.5^{\circ} \times 2.5^{\circ}\right)$ degree lat/lon. The operational data of the temperature analyzed according to [22]. However, the NCEP data set domain considered in the present work extended to $30^{\circ} \mathrm{N}-70^{\circ} \mathrm{N}, 15^{\circ} \mathrm{W}$ $-45^{\circ} \mathrm{E}$ for Europe with a grid mesh of $(9 \times 25)$ lat/lon. grids. Whereas the domain for the western Europe is $30^{\circ} \mathrm{N}-70^{\circ} \mathrm{N}, 15^{\circ} \mathrm{W}-5^{\circ} \mathrm{E}$ and the domain of the central Europe is $30^{\circ} \mathrm{N}-70^{\circ} \mathrm{N}, 5^{\circ} \mathrm{E}-25^{\circ} \mathrm{E}$, see Figure 1 . The grid mesh for each one of western and central Europe is $(9 \times 17)$ lat./lon. mesh. However, the period of study of the present work is only one season (92 days). The daily data of the NAO, SOI and El Nino 3.4 for the period of summer 2015 are used. The data obtained from the website through the internet of the Climate Prediction Centre at https://www.esrl.noaa.gov/psd/cgi-bin/data/composites/printpage.pl.

\subsection{Methodology}

Through the present work, Anomaly methodology has been used to analysis the surface air temperature over Europe. The climatic normal values of the surface

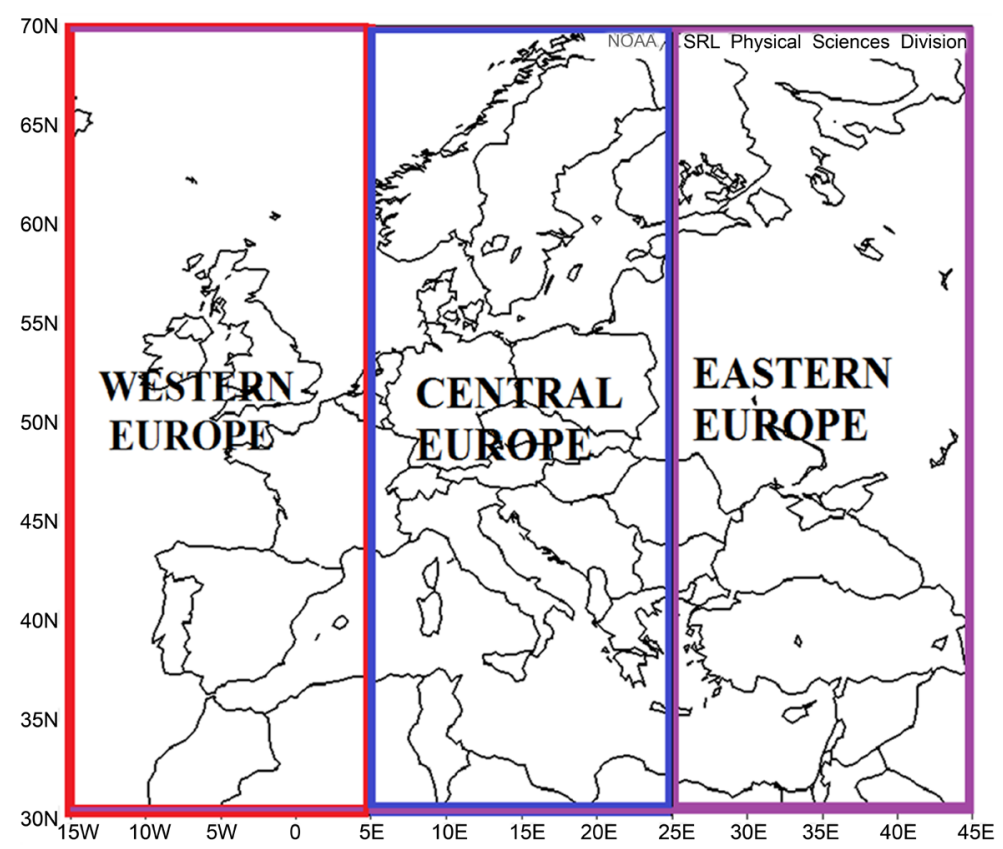

Figure 1. Map of the examined area. The western Europe domain of $\left[30^{\circ} \mathrm{N}-70^{\circ} \mathrm{N}, 15^{\circ} \mathrm{W}\right.$ $\left.-5^{\circ} \mathrm{E}\right]$, the central Europe domain of $\left[30^{\circ} \mathrm{N}-70^{\circ} \mathrm{N}, 5^{\circ} \mathrm{E}-25^{\circ} \mathrm{E}\right]$ and the whole domain of Europe of $\left[30^{\circ} \mathrm{N}-70^{\circ} \mathrm{N}, 15^{\circ} \mathrm{W}-45^{\circ} \mathrm{E}\right.$ ]. [Source according to:

http://www.nationsonline.org/oneworld/map/central-europe-map.htm and http://www.mapsofworld.com/europe/country-groupings/western-europe-map.html]. 
air temperature taken through the period (1981-2010). The 1981-2010 climate normal is National Centers for Environmental Information (NCEI's) latest threedecade averages of climatological variables, including temperature and precipitation [23]. In addition, the Hovmöller diagram (Latitude $\times$ Time), time cross-section technique, and a linear correlation coefficient technique by [24] had been used. For the purpose of the present study, we consider that the heat wave defined according to the daily anomaly to the composite mean of the surface air temperature and successive persistence days of this anomaly. Heat wave exists if the daily composite mean of the surface air temperature anomaly becomes more than or equal $+3^{\circ} \mathrm{C}$ and persist for five successive days or more over the area of study. Whereas, the comfort apparent temperatures ranged from $+14^{\circ} \mathrm{C}$ in central Europe to $+25^{\circ} \mathrm{C}$ in southern Spain, and it significantly higher than annual mean apparent temperatures between $+3.5^{\circ} \mathrm{C}$ and $+12.5^{\circ} \mathrm{C}$ [25]. However, the present data and methodology are chosen according to the main features of the heat waves.

\section{Results}

\subsection{The Variability of Daily Mean Surface Air Temperature over the Western Europe during Summer Season of the Year 2015}

The NCEP/NCAR reanalysis daily data of surface air temperature anomaly in the Western Europe through the period from 1 June to 31 August of the summer season of 2015 had been used. This data analyzed by time series analysis. In addition to that, the daily operational data of surface air temperature (station data) of the domain of the Western Europe through that period have been used in the present study. The latitude, time cross section method has used through this analysis. The results revealed that:

1) Figure 2 shows that almost all of Europe have a positive temperature anomaly

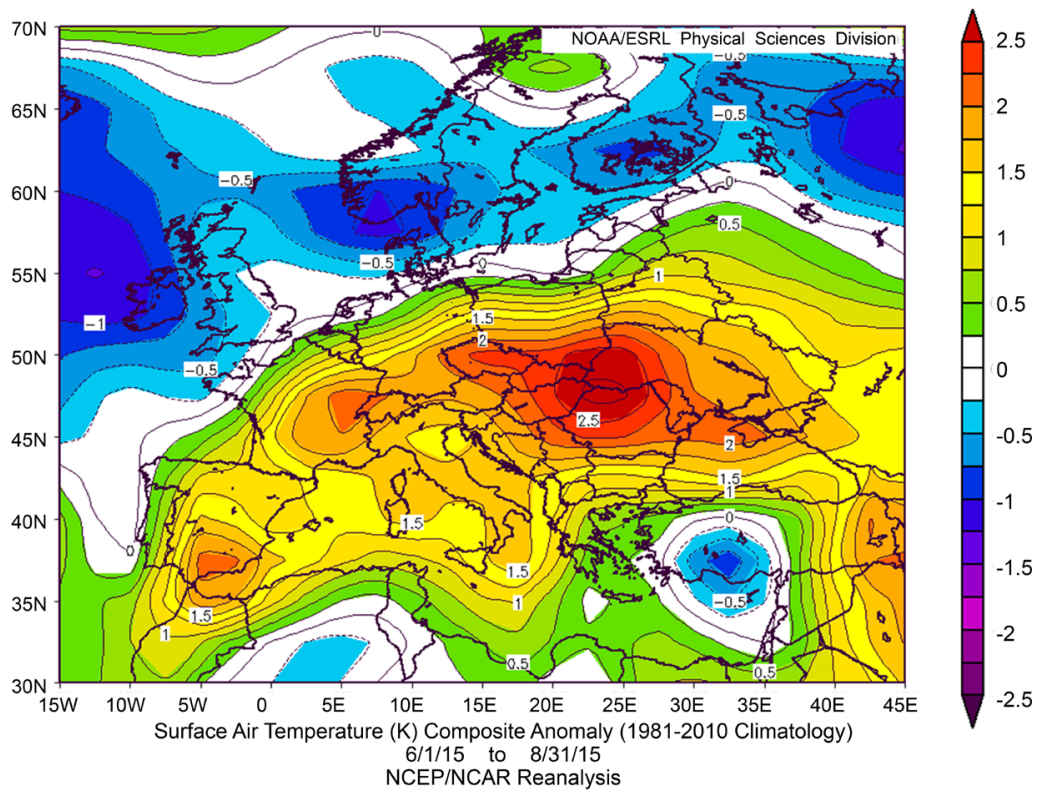

Figure 2. The distribution of the daily Surface Air temperature composite anomaly over Europe for the period from 1 June to 31 August of summer season of the year 2015. 
through the days of the summer season of the year 2015.

2) It is found that the mean surface air temperature anomaly over the Western Europe varies from day to day. The lowest anomaly of mean surface air temperature is $-7^{\circ} \mathrm{C}$ in the days of 14,15 and 16 June and on 15 and 16 August. The highest mean surface air temperature anomaly is $+11^{\circ} \mathrm{C}$ on 5 July and $+10^{\circ} \mathrm{C}$ on 3 and 4 July of summer 2015 . Moreover, almost days in July of 2015 has an extreme positive temperature anomaly, see Figure 3.

3) Analysis of the Hovmöller diagram (Latitude $\times$ Time) over the western Europe for the operational daily surface air temperature anomaly shows that almost of positive anomalies of the surface air temperature exist over the western Europe are located in the southern parts of western Europe (from $30^{\circ} \mathrm{N}$ to $45^{\circ} \mathrm{N}$ ) through the summer season of the year 2015. All of the Western Europe has positive mean daily surface air temperature for latitudes from $30^{\circ} \mathrm{N}$ to $70^{\circ} \mathrm{N}$, see Figure 4 .

According to the heat wave definition in Section (2), there are four distinct cases of a heat wave that exist over the Western Europe through the months of summer of the year 2015. These four cases of heat waves had total hot days of 52 days of the summer days of 92 days. Table 1 shows the date, time and duration

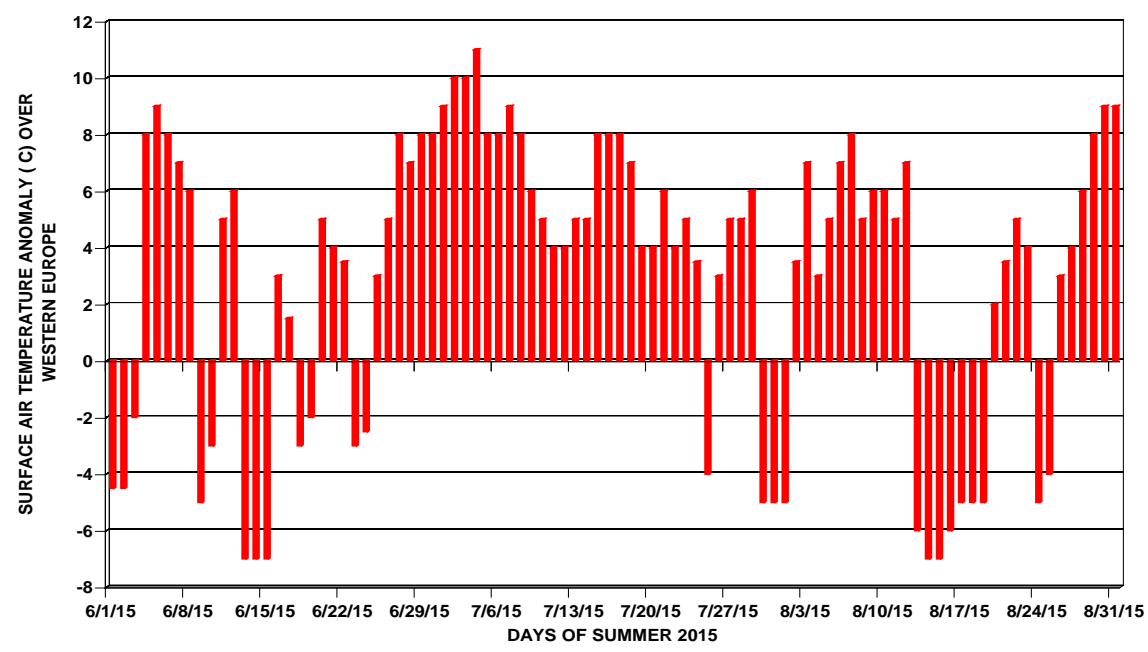

Figure 3. The Time series for the daily surface air temperature anomaly over the Western Europe through the months of June, July and August of the summer season of the year 2015.

Table 1. Heat wave cases that existed over the western Europe through a summer season of the year of 2015 through the period (1 June-31 August) [Calculated according to the defination of the heat wave].

\begin{tabular}{ccc}
\hline $\begin{array}{c}\text { Heat wave cases over western } \\
\text { Europe }\end{array}$ & Date Time & Duration Days \\
\hline Case (1) & 4 June-8 June & 5 days \\
Case (2) & 25 June-24 July & 30 days \\
Case (3) & 2 August-12 August & 11 days \\
Case (4) & 26 August-31 August & 6 days \\
\hline
\end{tabular}




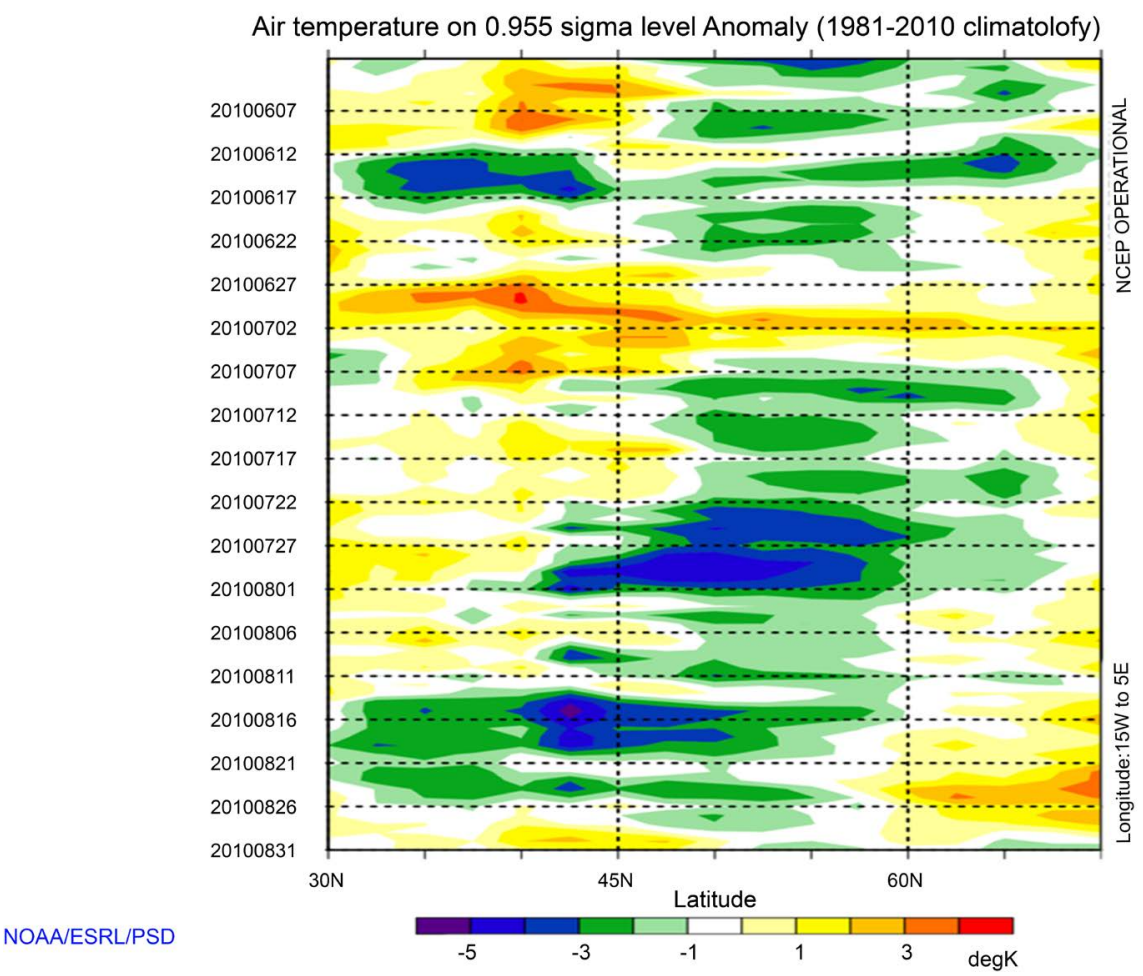

Figure 4. The Hovmöller diagram (Latitude $\times$ Time) showing the NCEP operational daily mean surface air temperature anomaly over the Western Europe $15^{\circ} \mathrm{W}$ to $5^{\circ} \mathrm{E}$, for the period of summer 2015 .

of each case of a heat wave that exists over the Western Europe during summer season (1 June-31 August) of the year of 2015.

\subsection{The Variability of Daily Mean Surface Air Temperature over the Central Europe during Summer Season of the Year 2015}

The NCEP/NCAR reanalysis daily anomaly of the surface air temperature in the central Europe through the period from 1 June to 31 August of the summer season of 2015 is used. This data analyzed by time series analysis. In addition, the gridded daily operational data of the surface air temperature collected from station data of the domain of the central Europe through that period used. The latitude, the time cross section method used through this analysis. The results revealed that:

1) Through the period of the first half of June month of the year 2015, mean of the surface air temperature has a positive anomaly over the central Europe. In contradicting to that, the mean of the surface air temperature has a negative anomaly over the central Europe through the period of next half of June 2015, as illustrated in Figure 5.

2) All the period from 1 July to the first half of August in the year 2015, the temperature anomaly has a positive value. Except that, the two days on 27 July and on 1 August of the year 2015, it has negative temperature anomaly. As it is clear in Figure 5.

3) Analysis of the Hovmöller diagram (Latitude $\times$ Time) over the central Europe 
for the daily surface air temperature anomalies shows that almost of positive anomalies of temperature over central Europe is located around near of latitude $45^{\circ} \mathrm{N}$ and north of it. However, near the southern and the northern boarding of the central Europe, there exist of the negative anomaly of mean surface air temperature through the study period. As shown in Figure 6.

4) There four distinct heat wave cases exist over central Europe through the period of the summer of the year 2015. These four cases of heat wave had total hot days of 67 days for the summer days of 92 days. The date, time and its duration of these heat waves have tabulated in Table 2.

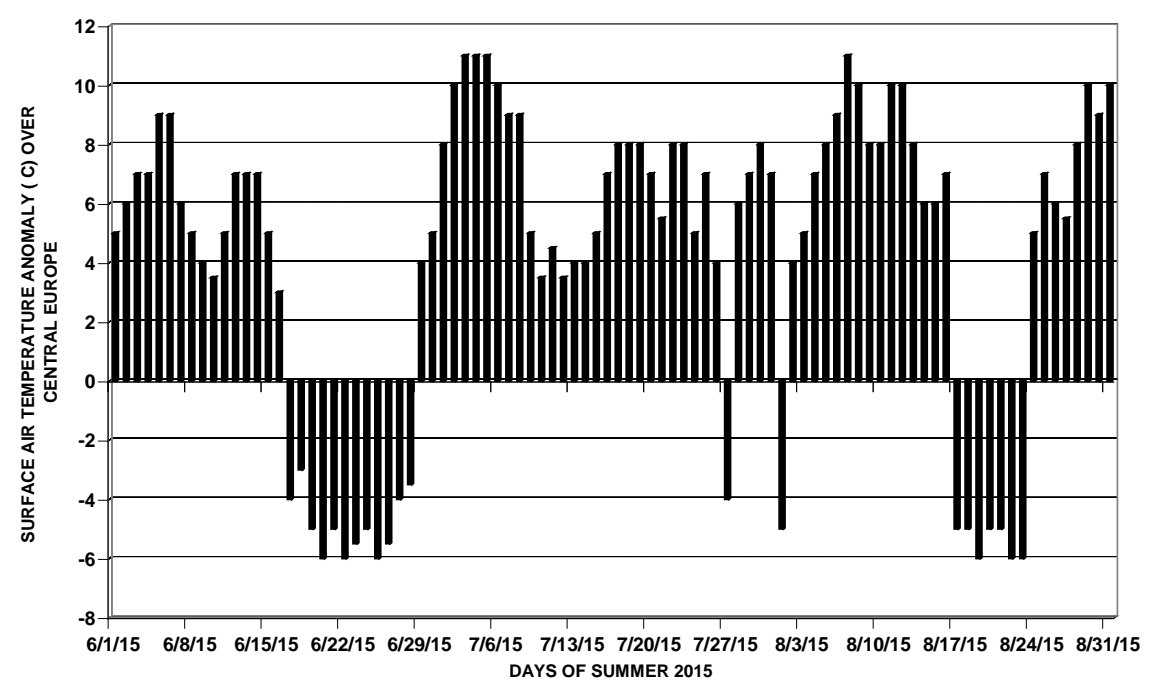

Figure 5. Time series for the daily surface air temperature anomaly over the central Europe through months of June, July and August of summer season of the year 2015.

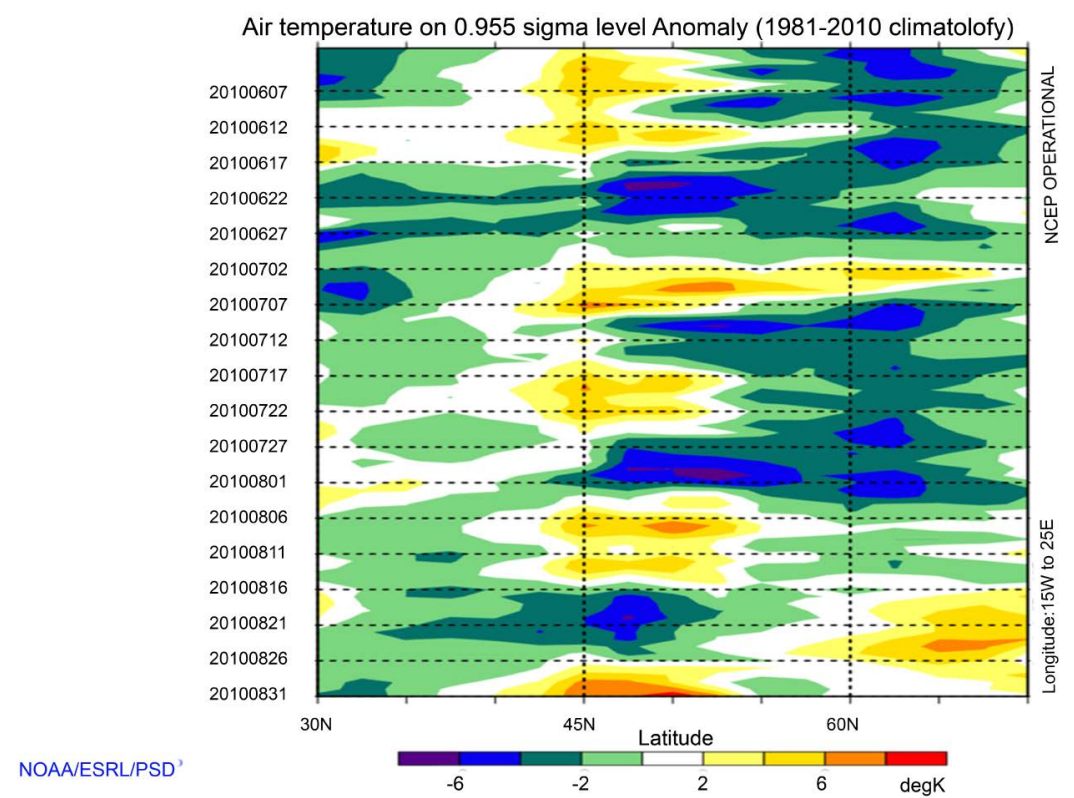

Figure 6. The Hovmöller diagram (Latitude $\times$ Time) showing the NCEP operational daily surface air temperature anomalies average over the central Europe $5^{\circ} \mathrm{E}$ to $25^{\circ} \mathrm{E}$, for the period of summer of the year 2015. 
Table 2. Heat wave cases that existed over the central Europe through the summer season of the year 2015 through the period (1 June-31 August) [Calculated according to the defination of the heat wave].

\begin{tabular}{ccc}
\hline Heat wave cases over central Europe & Date Time & Duration Days \\
\hline Case (1) & 1 June-16 June & 16 days \\
Case (2) & 29 June-26 July & 28 days \\
Case (3) & 2 August-16 August & 15 days \\
Case (4) & 24 August-31 August & 8 days \\
\hline
\end{tabular}

\subsection{Study the Relationship between the Heat Waves over Western and Central Europe and the NAO, SOI, and El-Nino 3.4 through Summer 2015}

Here we use the daily data of the anomaly of mean surface air temperature over western and central Europe and daily data of climatic indices NAO, SOI and El-Nino 3.4 through summer of the year 2015 to uncover the relationship between them. The time series analysis and correlation coefficient techniques have used in the present study to reach this goal. Analysis of these daily data sets revealed that:

1) The summer months, June, July and August of the year 2015 has a positive anomaly of the mean surface air temperature over western and central Europe. Through that period, NAO and SOI records negative values for all these three months. In contradicting to that, El-Nino 3.4 records an extreme positive anomaly values through the months of summer 2015, see Table 3.

2) Analysis of the daily mean surface air temperature over western and central Europe through this summer season illustrates that almost days of the heat waves have accompanied with negative phases of the NAO and SOI, as shown in Figure 7 and Figure 8 without a significant difference between the western and central Europe.

3) Positive anomaly values for the daily El Nino 3.4 overcentral Pacific Ocean $\left[\left(170^{\circ} \mathrm{W}-120^{\circ} \mathrm{W}\right)\right.$ and $\left.\left(5^{\circ} \mathrm{N}-5^{\circ} \mathrm{S}\right)\right]$ has been recorded through all days of the summer of the year 2015. So that, the day of heat waves over western and central Europe has accompanied by a positive phase of El Nino 3.4, as it is clear in Figure 9.

4) The correlation coefficient analysis between the heat waves over western and central Europe and NAO revealed that the NAO has a significant correlation with relatively short duration heat waves cases with duration $5,6,8,15$ days. As illustrated in Table 4 and Table 5.

5) SOI has an only significant correlation with a heat wave that persisted for the 15-day case over central Europe. As shown in Table 5.

6) El-Nino 3.4 has a significant correlation with heat wave cases over western and central Europe that persists 5, 6, 8 and 11 days. As it is clear from Table 4 and Table 5.

7) In the longest heat wave case over central Europe, 28 days, persistence, SOI has a high correlation coefficient rather than NAO and El Nino 3.4.As illustrated in Table 5. 


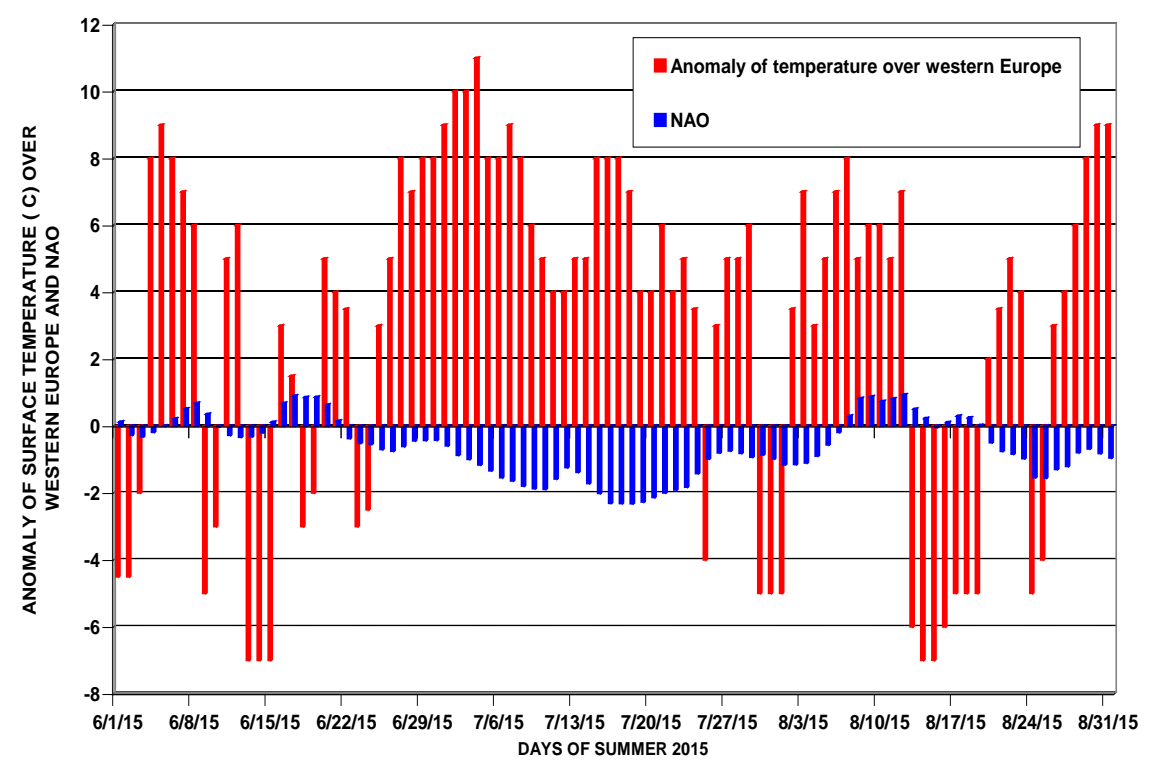

(a)

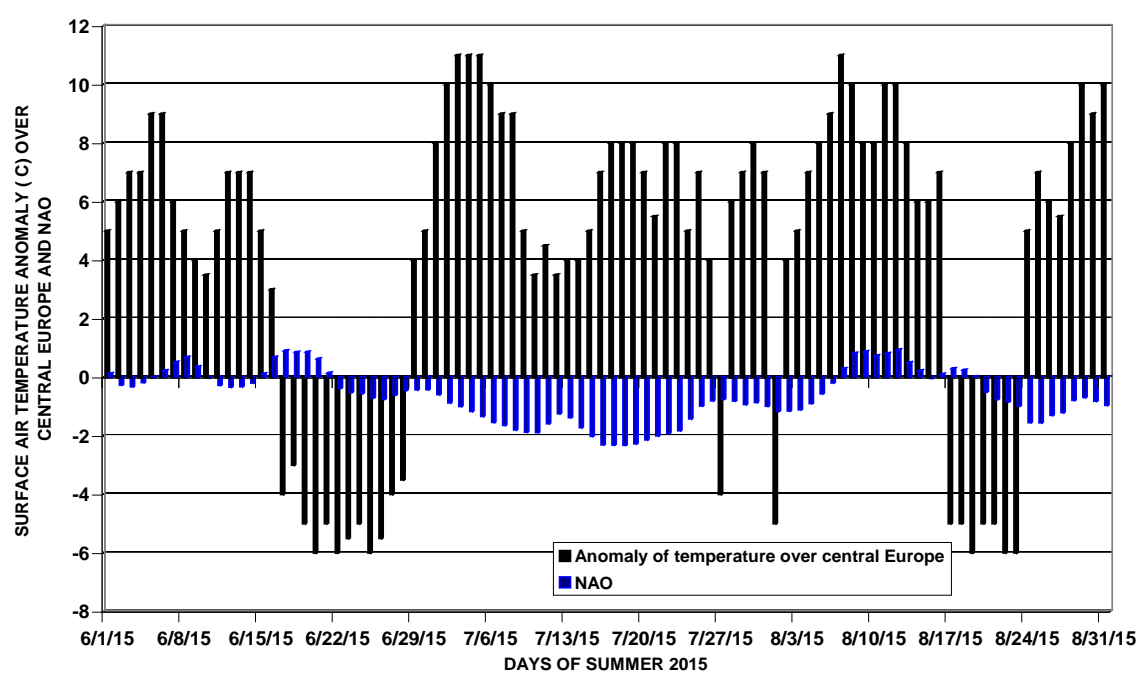

(b)

Figure 7. The time series of the surface air temperature anomaly and climatic index NAO for the period of summer 2015. (a) For the Western Europe; (b) For the central Europe.

Table 3. The maximum anomaly of the monthly surface air temperature over the western and central Europe and the climatic indices NAO, SOI, and El-Nino 3.4 monthly values through the summer season of the year 2015 .

\begin{tabular}{|c|c|c|c|c|c|c|}
\hline \multirow{2}{*}{ Summer Months } & \multicolumn{2}{|c|}{$\begin{array}{c}\text { Maximum anomaly in surface air } \\
\text { temperature }\left({ }^{\circ} \mathrm{C}\right)\end{array}$} & \multirow{2}{*}{ NAO } & \multirow{2}{*}{ SOI } & \multirow{2}{*}{ EL-NINO 3.4} & \multirow{2}{*}{$\begin{array}{l}\text { Anomaly of } \\
\text { EL-NINO } 3.4\end{array}$} \\
\hline & $\begin{array}{l}\text { Over western } \\
\text { Europe }\end{array}$ & $\begin{array}{l}\text { Over central } \\
\text { Europe }\end{array}$ & & & & \\
\hline JUNE 2015 & +1.81 & +1.53 & -0.07 & -1.70 & $28.96^{\circ} \mathrm{C}$ & $+1.32^{\circ} \mathrm{C}$ \\
\hline JULY 2015 & +5.30 & +6.70 & -3.18 & -2.40 & 28.78 & +1.60 \\
\hline AUGUST 2015 & +1.96 & +4.33 & -0.76 & -3.40 & 28.75 & +2.07 \\
\hline
\end{tabular}




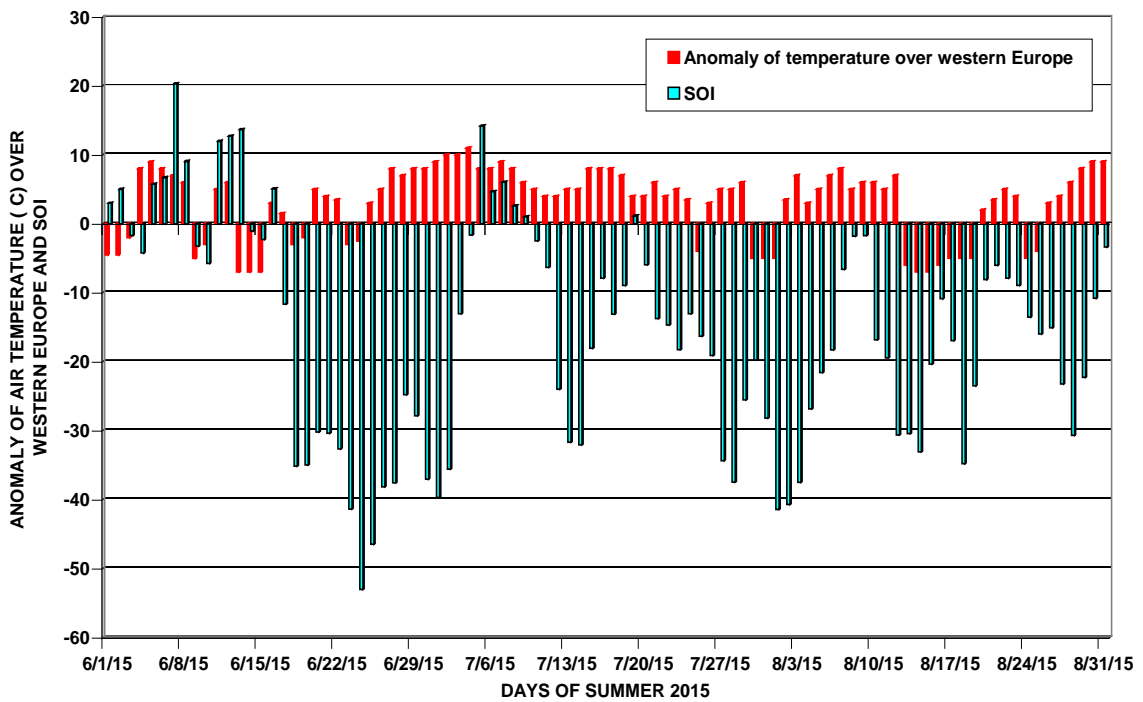

(a)

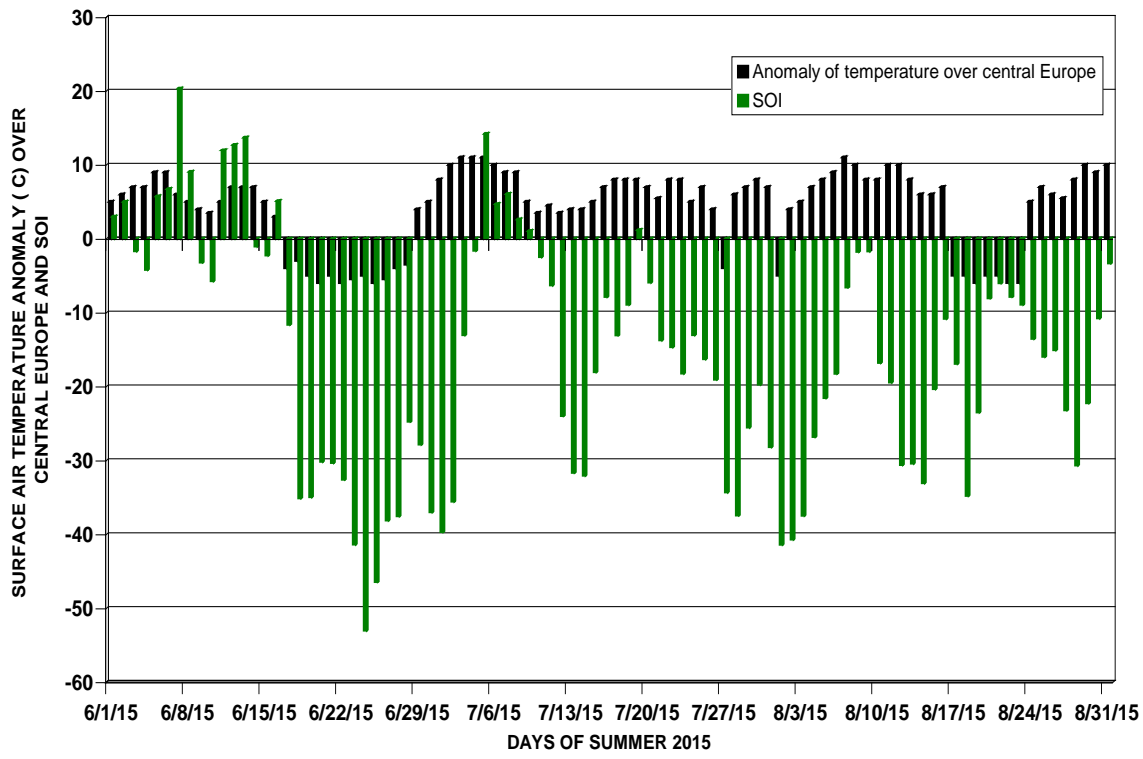

(b)

Figure 8. The time series of surface air temperature anomaly and climatic index SOI for the period of summer 2015. (a) For the western Europe; (b) For the central Europe.

Table 4. The correlation coefficient matrix between the anomaly of surface air temperature and the climatic indices NAO, SOI, and El Nino 3.4 during the heat waves cases that existed over the western Europe in summer 2015.

\begin{tabular}{|c|c|c|c|c|}
\hline \multirow{2}{*}{$\begin{array}{c}\text { Correlation } \\
\text { Coefficient } \\
\text { Climatic indices }\end{array}$} & \multicolumn{4}{|c|}{$\begin{array}{c}\text { Anomaly in surface air temperature over Western Europe in the } \\
\text { duration time of heat waves over western Europe }\end{array}$} \\
\hline & Case (1) & Case (2) & Case (3) & Case (4) \\
\hline $\mathrm{NAO}$ & $-0.85053^{*}$ & 0.250064 & 0.369849 & $0.786557^{*}$ \\
\hline SOI & -0.44131 & 0.110302 & 0.266473 & 0.452762 \\
\hline EL-NINO 3.4 & $-0.54957^{\star *}$ & 0.286092 & $0.549594^{* *}$ & $-0.973401^{*}$ \\
\hline
\end{tabular}

$\left.{ }^{\star}\right)$ With significant level $97 \%$. $\left.{ }^{* *}\right)$ With significant level $95 \%$. 


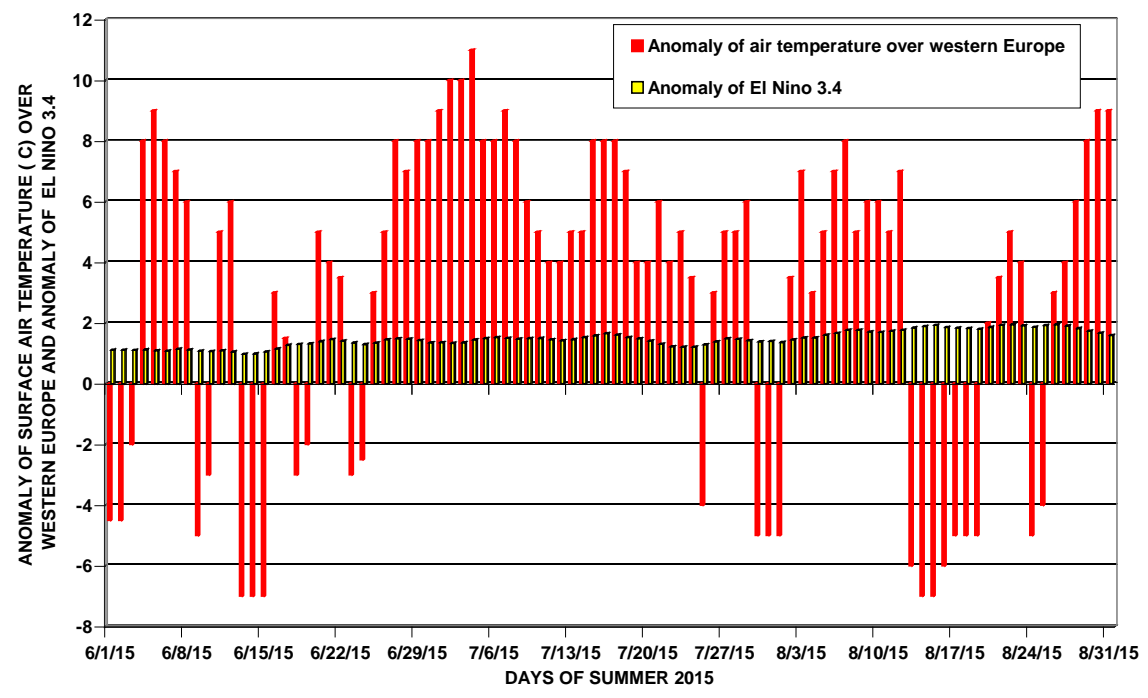

(a)

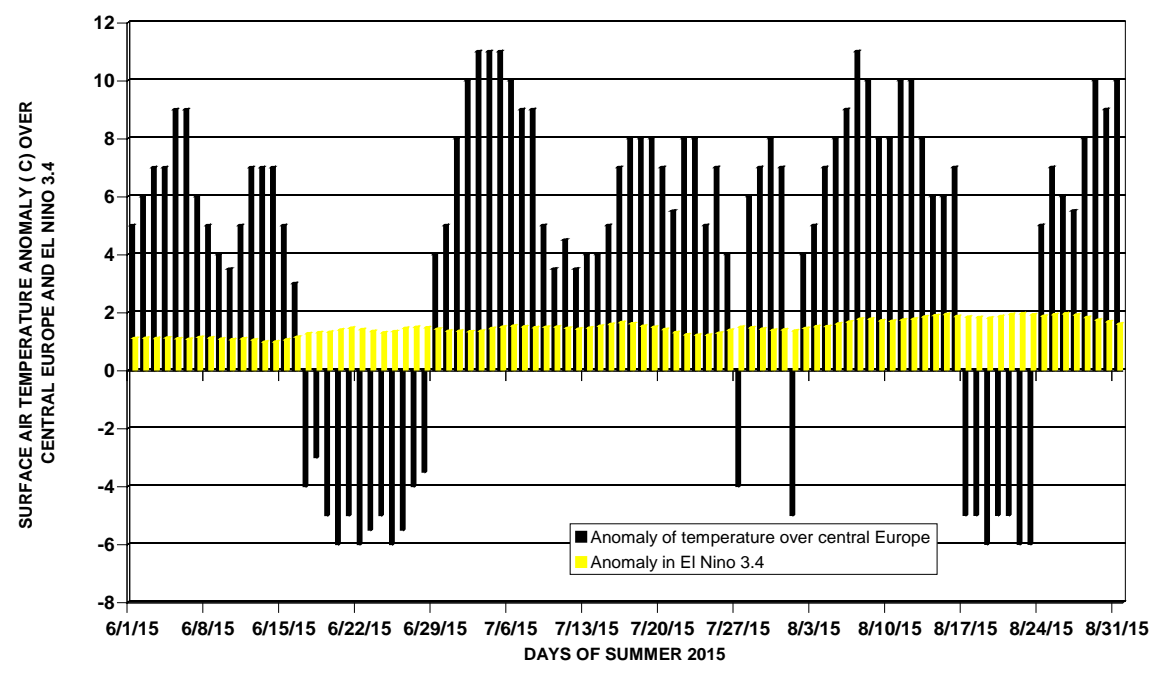

(b)

Figure 9. The time series of surface air temperature anomaly and El-Nino 3.4 for the period of summer 2015. (a) For the western Europe; (b) For the central Europe.

Table 5. The correlation coefficient matrix between anomaly of the surface air temperature and the climatic indices NAO, SOI, and El Nino 3.4 during the heat waves cases that existed over the central Europe in summer 2015.

\begin{tabular}{ccccc}
\hline Correlation & \multicolumn{4}{c}{ Anomaly in surface air temperature over central } \\
$\begin{array}{c}\text { Coefficient } \\
\text { Climatic indices }\end{array}$ & \multicolumn{2}{c}{ Europe in the duration time of heat waves over central Europe } \\
\cline { 2 - 5 } & Case (1) & Case (2) & Case (3) & Case (4) \\
\hline NAO & -0.42869 & -0.0405 & $0.702005^{* *}$ & $0.802216^{* *}$ \\
SOI & 0.21756 & 0.40849 & $0.623633^{*}$ & 0.202728 \\
EL-NINO 3.4 & -0.26534 & -0.00645 & 0.320737 & $-0.85319^{* *}$ \\
\hline
\end{tabular}

$\left(^{\star}\right)$ With significant level $97 \%$. $\left.{ }^{* *}\right)$ With significant level $95 \%$.

\section{Discussion and Conclusion}

The relationship between heat waves that exist over two distinct domains, the 
western and central Europe and the climatic indices NAO, SOI and El Nino 3.4 during the summer season of the year 2015 has studied. The NCEP/NCAR reanalysis daily data of mean surface air temperature for these two distinct domains over Europe through the period of ( 1 June-31 August) of the summer season of the year 2015 has been analyzed to set out the cases of heat waves and temperature variability over the western and central Europe. In addition, another set of data, the daily gridded operational data set of the mean surface air temperature over the western and central Europe during that period is used. These datasets are analyzed using of time series, anomaly technique, and correlation coefficient technique. The correlation coefficient technique has been used to study the relationship between heat waves that exist over the western and central Europe and the climatic indices NAO, SOI and El-Nino 3.4 during the summer of the year 2015. The results uncover that July of 2015 has a unique, maximum anomaly of the mean surface air temperature. It is $\left(+5.3^{\circ} \mathrm{C}\right.$ and $\left.+6.7^{\circ} \mathrm{C}\right)$ over the western and central Europe, respectively. Moreover, it is clear that through months (June, July, and August) of summer 2015, the NAO and SOI have negative phases. The lowest value of NAO (-3.18) has occurred in the month of July. The lowest value of SOI (-3.40) has occurred in the month of August of summer 2015. El-Nino 3.4 recorded an extreme increase in SST in the central of the Pacific Ocean through the study period. The highest recorded anomaly in El-Nino $3.4(+2.07$ ${ }^{\circ} \mathrm{C}$ ) has existed in August month of the year of 2015. The contradicting between SOI and El-Nino 3.4 phases during summer 2015 shows that year of 2015 is an ENSO year. For the purpose of the present study, the heat wave is defined as the case that has the daily composite mean of surface air temperature; anomaly becomes more than or equal to $+3^{\circ} \mathrm{C}$ and persists for 5 successive days or more over the area of study. In the western Europe, there exist four heat wave cases starting from 4 June to 31 August 2015. The first case started on 4 June and dissipated on 8 June with 5 days of duration. The second case is the longest persistence case that persists for 30 days from 25 June to 24 July of 2015. The third and fourth one existed on August month with durations 11 and 6 days. The total number of days of heat waves over the western Europe is 52 days of 92 days of the summer season of 2015. In the central Europe, four heat wave cases existed during the summer of the year 2015. The first case started on the first day of June and persisted until the day on 16 June with persistence of 16 days. The second case is the longest persistent case over the central Europe that persists for 28 days from 29 June to 26 July of the year 2015 . The third and fourth one existed on August month with durations of 15 and 8 days. The total number of days of heat waves over the central Europe is 67 days of 92 days of that summer season. Analysis of the Hovmöller diagram (Latitude $\times$ Time) anomaly of the NECP operational data of the mean daily surface air temperature over the western Europe $\left(15^{\circ} \mathrm{W}\right.$ to $\left.5^{\circ} \mathrm{E}\right)$, for the period of summer 2015 shows that the heat waves existed mainly over the southern part of western Europe between latitudes $30^{\circ} \mathrm{N}$ and $45^{\circ} \mathrm{N}$. Meanwhile, it was located at the mid-latitude and to the north of $45^{\circ} \mathrm{N}$ for cases of heat wave that existed over the central Europe through the 
period of study. The time series analysis of the mean daily surface air temperature over the western and central Europe revealed that almost the days of heat waves over the western and central Europe, the NAO and SOI had the negative phase through the study period. The NAO values in the first wave of June 2015 are oscillates between positive and negative values and it has a small value. Meanwhile, at the last half of August, it has completely negative values and its value reaches to -1.7 . The SOI almost has a negative phase except for the first half period of June 2015; it is oscillating between positive and negative values. El-Nino 3.4 has a positive anomaly value in all the periods of summer 2015 with a small anomaly in the first half of June 2015. The correlation coefficient study (with 93 numbers of degrees of freedom) between the mean daily surface air temperature over the western and central Europe and the climatic indices revealed that almost the days of heat waves had correlated to the NAO negative phase and ENSO positive phase through that summer season. The correlation coefficient analysis between the heat waves over the western and central Europe and NAO revealed that the NAO had a significant correlation with a relatively short duration in heat wave period with durations of 5, 6, 8, 15 days. It noticed that SOI only had a significant correlation with a heat wave that persisted for the 15-day case over central Europe. El-Nino 3.4 has a significant correlation with heat wave cases over the western and central Europe that persist 5, 6, 8 and 11 days. For the two longest period heat waves that persist for 28 and 30 days, it has found that the SOI has a high correlation coefficient rather than NAO and El-Nino 3.4 over central Europe. The results of the present study illustrated that the western and central Europe in the summer of the year 2015 lied under the control and influence of the northern and southern atmospheric interaction. The combination of the positive phase of ENSO and the negative phase of the NAO together leads to develop high stability-weather conditions and supply of the heat over Europe in the summer of the season of the year 2015. The present results encourage extending future studies that concern the heat waves existing over Europe. The role played by climatic indices and climatic variability on the occurrence and strength of the heat waves become more useful to study it and to forecast heat waves. Therefore, one can conclude that negative phase of the NAO and positive phase of ENSO well connected and controlled heat waves over the western and central Europe during the summer season of the year 2015.

\section{Acknowledgments}

The author hopes to thank the NOAA-CIRES Climate Diagnostics Centre (CDC). It is supporting the data, plots, and images. The CDC Center (Climate Diagnostics Centre) is located in Boulder, Colorado, USA. In addition, thanks to the Climate Prediction Centre (CPC) for providing the NAO, SOI, and El-Nino 3.4 data.

\section{References}

[1] The Weather Channel (2015) Heat Records Shattered in Germany, France, The Ne- 
therlands in June/July 2015 Europe Heat Wave.

https://weather.com/forecast/news/europe-heat-wave-record-highs-june-july-2015

[2] Comprendre (2015) Tout savoir sur la météo, le climat et Météo-France.

http://www.meteofrance.fr/actualites/26668131-nombreux-records-de-temperaturece-week-end

[3] García-Herrera, R., Díaz, J., Tricgo, R.M., Luterbacher, J. and Fischer, E.M. (2010) A Review of the European Summer Heat Wave of 2003. Critical Reviews in Environmental Science and Technology, 40, 267-306.

https://doi.org/10.1080/10643380802238137

[4] Katsafados, P., Papadopoulos, A., Varlas, G., Papadopoulou, E. and Mavromatidis, E. (2014) Seasonal Predictability of the 2010 Russian Heat Wave. Natural Hazards and Earth Systems Sciences, 14, 1531-1542.

https://doi.org/10.5194/nhess-14-1531-2014

[5] Fontana, G., Toreti, A., Ceglar, A. and De Sanctis, G. (2015) Early Heat Waves over Italy and Their Impacts on Durum Wheat Yields. Natural Hazards and Earth Systems Sciences, 15, 1631-1637. https://doi.org/10.5194/nhess-15-1631-2015

[6] Barriopedro, D., Fischer, E.M., Luterbacher, J., Trigo, R.M. and Herrera, G.R. (2011) The Hot Summer of 2010: Redrawing the Temperature Record Map of Europe. Science, 332, 220-224. https://doi.org/10.1126/science

[7] Hafez, Y.Y. (2012) Blocking Systems Persist over North Hemisphere and Its Role in Extreme Hot Waves over Russia During Summer 2010. In: Yucel, I., Ed., Atmos pheric Model Applications, InTech. https://doi.org/10.5772/33810

[8] Trenberth, K.E. and Fasullo, J.T. (2012) Climate Extremes and Climate Change: The Russian Heat Wave and Other Climate Extremes of 2010. Journal of Geophysical Research, 117, D17. https://doi.org/10.1029/2012JD018020

[9] Barnston, A.G. and Livezey, R.E. (1987) Classifications, Seasonality, and Persistence of Low-Frequency Atmospheric Circulation Patterns. Monthly Weather Review, $115,1083-1126$. https://doi.org/10.1175/1520-0493(1987)115<1083:CSAPOL $>2.0 . C O ; 2$

[10] Jones, G.S., Stott, P.A. and Christidis, N. (2013) Attribution of Observed Historical Near-Surface Temperature Variations to Anthropogenic and Natural Causes Using CMIP5 Simulations. Journal of Geophysical Research, 118, 4001-4024.

https://doi.org/10.1002/jgrd.50239

[11] Hurrell, J.W. (1995) Decadal Trends in the North Atlantic Oscillation: Regional Temperatures and Precipitation. Science, 269, 676-679. https://doi.org/10.1126/science.269.5224.676

[12] Jones, P.D., Jónsson, T. and Wheeler, D. (1997) Extension to the North Atlantic Oscillation Using Early Instrumental Pressure Observations from Gibraltar and SouthWest Iceland. International Journal of Climatology, 17, 1433-1450. https://doi.org/10.1002/(SICI)1097-0088(19971115)17:13<1433::AID-JOC203>3.0.C $\underline{\mathrm{O} ; 2-\mathrm{P}}$

[13] Wright, C.K., de Beurs, K.M. and Henebry, G.M. (2014) Land Surface Anomalies Preceding the 2010 Russian Heat Wave and a Link to the North Atlantic Oscillation. Environmental Research Letters, 9, Article ID: 124015.

[14] Della-Marta, P.M., Luterbacher, J., von Weissenfluh, H., Xoplaki, E., Brunet, M. and Wanner, H. (2007) Summer Heat Waves over Western Europe 1880-2003, their Relationship to Large-Scale Forcing and Predictability. Climate Dynamics, 29, 251275. https://doi.org/10.1007/s00382-007-0233-1

[15] Philander, S.G.H. (1990) El Nino, La Nina, and the Southern Oscillation. Academic Press, Waltham, 293 p. 
[16] Singh, P., Chowdary, J.S. and Gnanaseelan, C. (2013) Impact of Prolonged La Niña Events on the Indian Ocean with a Special Emphasis on Southwest Tropical Indian Ocean SST. Global and Planetary Change, 100, 28-37.

[17] Rong, Z., Liu, Y., Zong, H. and Cheng, Y. (2007) Interannual Sea Level Variability in the South China Sea and Its Response to ENSO. Global and Planetary Change, 55, 257-272.

[18] Parker, T.J., Berry, G.L., Reeder, M.J. and Nicholls, N. (2014) Modes of Climate Variability and Heat Waves in Victoria, Southeastern Australia. Geophysical Research Letters, 41, 6926-6934. https://doi.org/10.1002/2014GL061736

[19] Keellings, D. and Waylen, P. (2015) Investigating Teleconnection Drivers of Bivariate Heat Waves in Florida Using Extreme Value Analysis. Climate Dynamics, 44, 3383-3391. https://doi.org/10.1007/s00382-014-2345-8

[20] Perkins, S.E., Argüeso, D. and White, C.J. (2015) Relationships between Climate Variability, Soil Moisture, and Australian Heatwaves. Journal of Geophysical Research, 120, 8144-8164. https://doi.org/10.1002/2015JD023592

[21] Kalnay, E., Kanamitsu, M., Kistler, R., et al. (1996) The NCEP/NCAR 40-Year Reanalysis Project. Bulletin of American Meteorological Society, 77, 437-471. https://doi.org/10.1175/1520-0477(1996)077<0437:TNYRP>2.0.CO;2

[22] Trenberth, K.E. and Olson, J.G. (1988) Evaluation of NMC Global Analyses: 197987. NCAR Technical Note TN-299+STR, National Center for Atmospheric Research, Boulder, CO, $82 \mathrm{p}$.

[23] Arguez, A., Durre, I., Applequist, S., Vose, R.S., Squires, M.F., Yin, X., Heim Jr., R. and Owen, T.W. (2012) NOAA'S 1981-2010 U.S. Climate Normals: An Overview. Bulletin of the American Meteorological Society, 1687-1697. https://doi.org/10.1175/BAMS-D-11-00197.1

[24] Spiegel, M.R. (1961) Theory and Problems of Statistics. Schaum, 359.

[25] Ballester, J., Robine, J.M., Herrmann, F.R. and Rod, X. (2011) Long-Term Projections and Acclimatization Scenarios of Temperature-Related Mortality in Europe. Nature Communications, 2, Article No. 358. https://doi.org/10.1038/ncomms1360

\section{Scientific Research Publishing}

Submit or recommend next manuscript to SCIRP and we will provide best service for you:

Accepting pre-submission inquiries through Email, Facebook, LinkedIn, Twitter, etc. A wide selection of journals (inclusive of 9 subjects, more than 200 journals)

Providing 24-hour high-quality service

User-friendly online submission system

Fair and swift peer-review system

Efficient typesetting and proofreading procedure

Display of the result of downloads and visits, as well as the number of cited articles

Maximum dissemination of your research work

Submit your manuscript at: http://papersubmission.scirp.org/

Or contact gep@scirp.org 